DOI: https://doi.org/10.22182/pnb.2122021.9

Milan Krstic ${ }^{*}$

University of Belgrade - Faculty of Political Science

\title{
CONTINUITY AND CHANGES IN THE US FOREIGN POLICY TOWARDS THE WESTERN BALKANS DURING THE FIRST YEAR OF BIDEN'S PRESIDENCY: THIRD OBAMA'S OR SECOND TRUMP'S TERM?
}

\begin{abstract}
Many analysts expected a radical change in President Joseph Biden's foreign policy compared to the foreign policy of previous President Donald Trump. A year after his electoral victory, opinions about how much Biden actually changed in the US foreign policy vary from those who see it as a revolutionary change to those who perceive it as a difference only in tone and continuity in the majority of crucial policy aspects. This paper aims to contribute to this debate by addressing the issues of continuity and changes in the new administration foreign policy towards the Western Balkans. Although many expected that Biden's policy to the region would be much more similar to President Barrack Obama's or even President Bill Clinton's approach, this paper claims that the new administration has a lot in common with the course of the previous President Donald Trump. There are also some changes and modifications, but they seem to be less crucial than the elements of continuity that exist between Biden's and Trump's administrations' foreign policy towards this region. The paper also addresses the causes of this continuity and claims that the main reason for that are structural factors on the level of the international system. However, some reasons for the continuity are also on the state (internal) and individual levels of analysis.
\end{abstract}

Keywords: US foreign policy, Western Balkans, Biden, Trump, continuity, change, levels of analysis

Contact: milan.krstic@fpn.bg.ac.rs 


\section{INTRODUCTION}

The United States of America (US) present one of the most important global actors. From the prism of the Western Balkans, America is still one of the most influential foreign powers which substantially influences regional affairs. Considering the election of Joseph Biden for the US President in November 2020, many expected "revolutionary change" (Andelman 2021) in comparison to the foreign policy of Donald Trump. "America First" unilateral approach was expected to be abandoned, with the US returning to multilateralism (with American leadership in solving the most critical global problems and protecting its interests) and focusing on the maintenance of its alliances and promotion of values such as democracy and human rights. Many expected the complete return to the pre-Trump period, or "Obama's (or even Clinton's) third term" (Abrams 2021). Consequentially, there were similar expectations regarding the US policy towards the Western Balkans, considering that many criticized Trump's approach to the region as too soft towards some actors such as Serbia; non-coordinated with the EU; not focused enough on the issues such as democracy and human rights etc. However, certain analysts say that the radical change in the general US foreign policy did not occur and that the White House "changed tone, but not policies" (Labott 2021).

This paper aims to contribute to the discussion about the patterns of continuity and change in Biden's foreign policy, focusing on the case of the Western Balkans. The paper claims that the approach of Biden's administration to this region contains more elements of continuity than change compared to the course of its Republican predecessor. Substantial goals and instruments remained the same, with some modifications mostly of tone (narrative) and not much of policy. Therefore, it seems that Biden's policy so far looks more similar to the hypothetical "Trump's second term" (although with some differences) than to the ideal type of the "Obama's third term". Paper also claims that structural factors are the most important reason for this continuity. However, some parts of the explanation for the patterns of continuity and change are visible on the state (internal) and individual levels of analysis. In the first section of the paper, we will present the main elements of continuity that exist in the new administration's foreign policy to the Western Balkans. In the second section, we will show specific changes that are visible compared to the previous administration. Finally, the third section will analyze potential explanations for these patterns of continuity and change coming from the three levels of analysis in 
International Relations: 1) Level of the international system (structural level); 2) State (internal) level; 3) Individual level.

\section{CONTINUITY IN NEW ADMINISTRATION'S POLICY TOWARDS THE WESTERN BALKANS}

There is a significant continuity with Trump's approach in many aspects of Biden's foreign policy towards the Western Balkans. This continuity could be summed up in the phrase: "more Carrots, less sticks". Considering the legacy of Clinton's and (to some extent) Obama's administrations in the Western Balkans, when the US was very willing to use "sticks" and to punish certain states, it was expected that Biden's administration would be more inclined to use coercive measures such as economic or diplomatic sanctions to enforce the implementation of its goals in the Western Balkans. The most explicit statement that the US will not follow the harsh approach from the past was delivered by Gabriel Escobar, who said that many of the people analysts and politicians "continue to see their leadership through the prism of 1990s, we don't - we see it through the prism of $21^{\text {st }}$ century" (US Embassy Serbia 2021). There is also significant continuity in the main goals and principles of the US Western Balkan foreign policy. In the following paragraphs, we will present the essential aspects of continuity in the US foreign policy towards the Western Balkans.

\section{Focus on economic integration of the region}

One of the essential characteristics of Trump's administration Western Balkan policy was prioritizing economic integration. It was visible through at least two concrete examples. The first was that the US focused on the economic normalization of relations between Belgrade and Pristina instead of pressuring for a faster political settlement, as was mostly the case during the previous Obama administration (Nedeljkovic, Krstic 2021). The second was colossal support that the Trump administration gave to the "Mini-Schengen" plan of establishing a regional common market announced by Serbian, North Macedonian and Albanian leaders in fall 2019 (US Mission Germany 2019). Support was not only rhetorical, but the US even pressured authorities in Pristina to join this project, which Pristina formally accepted with the signing of the Washington Papers in September 2020 (CDDRI 2020, 9). For Trump's administration, regional economic integration was a bigger priority than the EU accession of the region or solving the remaining 
open political issues in the Balkan. It was contrary to the reserved EU stance towards the Mini-Schengen initiative, which it never officially supported (Đukanović, Krstić 2021, 18-19). Instead of that, the EU tried in fall 2020 to promote its own form of regional economic integration labelled Common Regional Market, which would include all Western Balkan entities, and which would be under the umbrella of the Berlin Process and, therefore, the EU (Đukanović, Krstić 2021, 19-20).

Considering that Biden's administration announced that one of its goals is to rebuild a strong alliance with the EU (Atlantic Council 2021), it was expected that the new administration would completely align with the EU approach to the region, unlike its Republican predecessors. However, almost a year after Biden's victory, it seems that there is a clear continuity with the approach of Trump's administration. Deputy Assistant Secretary of State for Europe and Eurasia Gabriel Escobar announced at the Belgrade Security Forum that the US see economic integration of the region as one of the priorities and that the best road to the overall progress of the region (including the eventual solving of the open issues and the EU membership) is to focus on economic development and regional economic cooperation (Ranković 2021). He underlined the same attitude on the To Be Secured Forum in Montenegro (Milic 2021) and during the hearing organized in the House of Representatives' Subcommittee for Europe, Energy, the Environment and Cyber (House Foreign Affairs Committee 2021). Escobar emphasized that the US support both Open Balkan (the renamed MiniSchengen) and Common Regional Market and that it is willing to help the region to implement these plans for economic integration (House Foreign Affairs Committee 2021). Obviously, the new administration did not change its support to the Mini-Schengen/Open Balkan despite the reluctance of the EU to support this initiative, nor did it change its central assumption that closer economic cooperation and development should precede any political settlement of the open political issues in the region. This was a significant pattern of continuity with Trump's administration.

\section{A more balanced approach to the issue of Kosovo}

The bottom line of all US governments since George W. Bush is the same: they treat Kosovo as an independent country and consider that Belgrade should eventually recognize it to achieve the final settlement of the Kosovo issue. Trump's administration was not an exception. In his letter to President Vucic in February 2019, President 
Trump explicitly stated that the US "believe that the mutual recognition should be the central element of normalization" (EWB 2019). Even during the Washington talks in September 2020, the Serbian delegation claimed that Americans tried to negotiate mutual recognition between sides. Still, they allegedly shortly gave up this idea since it became evident that Belgrade would not accept it at that moment by any chance (Beta 2020). In this aspect, Biden's administration has continuity with Trump's, considering that President Biden has mentioned a similar formulation in his letter to Vucic in February 2021, while State Department also stated that the dialogue should be "centered on mutual recognition" (RSE 2021).

However, to some extent, Trump's administration was different from Obama's in this regard since it was comparatively a bit more flexible and balanced. First, there were no explicit pressures on Belgrade to make concessions, such as those the US made with the EU from 2011 to 2016 (Nedeljković, Krstić 2021). There was no use of threatening discourse or ultimatums towards Belgrade. Secondly, when Pristina introduced $100 \%$ tariffs on Serbian goods in late 2018, the US side was crucial for the eventual removal of these measures in 2020. It seems that Trump's administration even played a role in the following change of government in Pristina, when the more compromising Avdulah Hoti on the position of prime minister, instead of Aljbin Kurti (Kakissis 2020). These were obvious signs that Pristina is not considered anymore to be "always right". Thirdly, at some point in time, the US explicitly stated that there is room for "creative solutions", which was considered by some actors to be informal support to delineation and territory swap as a model for a final solution. Such a solution was allegedly favored by then-National Security Advisor John Bolton (RFE/RL 2018). Finally, the decision to focus on economic issues (instead of focusing on complicated political problems) signaled that the main approach of the US is not anymore to convince Belgrade to "accept the reality" as soon as possible. Washington became aware that this process should be more balanced and gradual to achieve any further moves towards normalization.

Considering that many people in Biden's administration in charge of foreign policy had a pro-Albanian attitude during the 1990s, it was expected by some analysts that the new administration would put substantial pressure on Belgrade to recognize Kosovo as soon as possible. It was also expected that the new administration would denounce Washington papers signed in September 2020 by representatives of Belgrade and Pristina since this was a symbol of a unilateral effort of Trump's administration that was not coordinated 
with the EU. It did not occur, and Biden's administration continued with a more balanced approach. Secretary of State Antony Blinken gave credits to Richard Grenell and Trump's administration for this achievement already on the hearing in Senate's Committee before he was formally vetted for this position (Kosovo online/Gazeta express 2021). The State Department also emphasized that they expect both sides "to implement their Washington Commitments in support of the goal of full normalization" (Price 2021).

It seems that dialogue between Belgrade and Pristina is important for the new administration but that it will not punish sides in the dialogue if the agreement is not reached. In the mentioned speeches, Gabriel Escobar underlined that a political solution for Kosovo is desirable but focused primarily on the region's economic development, which is very similar to the previous approach of Richard Grenell. Escobar mentioned that mutual recognition would be a preferable solution for the US but signaled that this is not ultimately the only acceptable solution, and that Washington might support other solutions which would be acceptable to both sides in the dialogue (House Foreign Affairs Committee 2021). The fact that Christopher Hill is nominated for the next US ambassador in Belgrade is also very interesting. Two years ago, while retired, he said he would leave territorial and status issues for the end of the process while navigating the dialogue towards solving practical questions (Savković 2021). This "flexibility" was very similar to some people's attitudes in Trump's administration at that time, such as John Bolton.

\section{Pragmatic cooperation with all Western Balkan leaders}

One of the characteristics of Trump's approach to the region (and more broadly) was that it did not emphasize the state of democracy and human rights in countries with which it cooperates (unless it helped criticize those defined as rivals or enemies). This was also the case with the previous administration's policy to the Western Balkans, where many states suffered from a significant decrease in the quality of democracy and civil rights, according to independent sources such as Freedom House. 1 It was expected that Biden's administration would make a more significant distance from leaders of countries with democratic deficits. Also, it was expected that they would be harsher towards actors such as Serbian member of Bosnian Presidency Milorad Dodik (who was sanctioned during Obama's administration), who many Americans perceive as responsible for the rise of tensions in the region, or towards

1) For example, Serbia is in a constant decrease since 2015, and it declined to the status of "Transitional or hybrid regime" in its democracy score in 2020 (Freedom House 2021). 
the new government in Montenegro, since certain pro-Russian parties in Democratic Front support it.

However, the new administration continued with the approach of their Republican predecessors. Escobar explicitly stated that the US will support democracy, but not through distancing from cooperation with Western Balkan leaders (US Embassy Serbia 2021). Despite open critics and some modest threats for claims about the potential secession of Republika Srpska (Politika 2021), the US still did not put any substantial pressure on Milorad Dodik, and it is still trying to avoid additional escalation in relations with Banja Luka. Also, it has excellent cooperation with new authorities in Montenegro. A more pragmatic approach that emphasizes the benefit that the US might have from collaboration with confident leaders to fulfil its goals prevailed over the policy, which would be more rigid towards them because of certain shortcomings. Of course, that does not mean that the US is only for the status quo and that it would not support certain more prodemocratic changes in the region, but it will certainly not push for it on its own. In this regard, there is also a considerable similarity with Trump's approach, considering that in 2017 the US diplomats helped to solve the political crisis in Skopje and the change of government in Northern Macedonia when Zaev's government replaced the regime of Nikola Gruevski (Kuzmanovski 2017). Therefore, it seems that there is much more continuity than change in comparison to the previous US administration's policy.

\section{Countering the rising influence of China and Russia}

Trump's anti-Chinese policy was in massive contrast to Obama's "pivot to Asia" strategy and an attempt to build close cooperation ties with Bejing. Considering that Biden's administration was portrayed by many as "Third Obama's term" (Singh 2020), it was expected that the new administration would decrease tensions between Bejing and Washington. However, the new administration has more continuity than discontinuity with the previous in its approach to China (Bisley 2021). Therefore, it is not surprising that the new administration has a similar stance towards Chinese influence in the Western Balkan. American approach focuses on the challenges which might arise from the more significant Chinese impact on the economy and politics in the Balkans. The opening of the DFC office during Trump's administration in Belgrade was part of the broader approach to counter the rising financial influence of Chinese loans in the region. Also, the Washington Papers signed by president Vucic in September 2020 had an article in which 
Serbia promised that it would not buy $5 \mathrm{G}$ technology from "untrusted vendors", directed towards Chinese company Huawei (CDDRI 2020, 10-11). The new administration has not made any similar moves so far, and even the level of future activities of DFC seems unclear at the moment. However, it explicitly stated that reducing the Russian and Chinese influence in the region will be one of the goals of the US (House Foreign Affairs Committee. 2021), which means that they will follow the path regarding China set by the previous administration.

This will also be the case regarding the US stance towards the influence of Moscow in the region. Although some critics portrayed Trump as being too soft and sympathetic towards Vladimir Putin, in reality, his administration made a lot of effort to counter growing Russian influence in the Western Balkans. This was primarily visible in the energetics sector, where it tried to reduce the region's dependence on the import of Russian gas. Significant projects of building terminals in Greece and Croatia to import Liquid Natural Gas from the USA were developed during the previous administration. Americans hoped this could be an alternative for Russian gas and help reduce the political influence of Moscow. These measures were especially focused on Serbia, which accepted the clause that it would diversify its energy sources in the mentioned Washington papers from September 2020 (CDDRI 2020, 10). Biden's administration will probably rhetorically emphasize the importance of reducing Russian influence in the region compared to the previous administration. Still, in a nutshell, it will continue the path set by the last administration in this regard as well.

\section{Expansion of NATO}

Despite some controversial moments which questioned the firmness of NATO's position in the Western Balkans ${ }^{2}$, the previous Republican administration continued with the NATO enlargement process. During the mandate of Donald Trump, Montenegro and Northern Macedonia formally joined NATO. Northern Macedonia managed to do so because of the Prespa Agreement and the final solving of the name issue with Greece, whose achievement was substantially backed by the USA. Biden's administration will follow this suit and support further enlargement of NATO to Bosnia and Herzegovina. Considering that Assistant Secretary for Europe and Eurasia Karen Donflried has a substantial background in promoting Euro-Atlantic integration and NATO enlargement through her engagement in the

2) One of the such examples was Trump's comment that he would not start a World War III for Montenegro and send his son to fight for it (Macias, Higgins 2018) 
German Marshall Fund of the US, this issue will probably be one of the most important for her. Regarding Serbia, it is expected that the new administration will stress out that it respects Serbian neutrality but that it hopes for deepening and widening of cooperation with Serbia through the Partnership for Peace program. Therefore, this aspect will also present the continuity with Trump's administration.

\section{$* * *$}

Besides the mentioned priorities, there will be undoubted continuity between the previous and the new administration in the common goals of US foreign policy, such as protection of the US citizens, protection of US companies and promotion of their commercial interest, fight against drug smuggling and organized crime, and fight against terrorism and violent radicalization. The US constantly cooperates with all countries in the region to pursue these vital goals for American interests and security. Considering everything mentioned, it seems that Biden's administration will make no "U-turns" in its policy towards the Western Balkans, but that it will follow the main goals of the previous administration's approach.

\section{CHANGES IN THE APPROACH OF THE NEW ADMINISTRATION TOWARDS THE WESTERN BALKANS}

Despite a significant amount of continuity, some differences are also visible in the new administration's approach. The announced claim that the US will use tools for the $21^{\text {st }}$ century does not mean that some targeted sanctions towards individuals won't be applied if necessary. Therefore, sticks (although less important than carrots) seem to be more visible today than they used to be during the previous administration. "Modernization" of the existing executive order for sanctions against Western Balkan individuals from 2001 by the inclusion of corruption as a potential reason for sanctioning proves that the US is calibrating these instruments as well (RFE/RL 2021). Also, the US military will remain in the region through its presence in the KFOR mission and various NATO activities, and the new administration definitely won't continue with Trump's sometimes NATO-sceptic rhetoric. Moreover, it is still not obvious how will Americans use the "positive" economic instruments (carrots) to coopt Western Balkan actors. ${ }^{3}$ These differences point out

3) For example, the level of activity of the DFC in Belgrade is questionable. The decision to remove John Jovanovic from the head office position raised doubts about Biden's administration plans. Still, it seems that the office in Belgrade will remain open. At the same time, the level of its activity will probably be determined by measuring how much Serbia and 
that Biden's policy towards the region is not quite a "Trump's second term". However, these differences seem to be smaller and less critical than patterns of continuity. In the following paragraphs, we will present the most important differences in the US foreign policy towards the Western Balkans and point out that they are not radical and that they are limited.

\section{Stronger support for the integration of the region to the $E U$}

Although Trump's administration formally supported the accession of the Western Balkans to the EU, it did not put too much effort to support this process, neither did it emphasize it too much in its rhetoric. It seemed that Washington did not care too much about the fast integration of the region to the EU, as it cared about strengthening its own partnerships with Western Balkan states and countering the influence of Russia and China. Biden's administration has so far put a particular emphasis on the integration of the region to the EU as one of its goals. In State Department's document named "US Commitment to the Western Balkans" from April 2021, the first sentence stated that "The United States is committed to supporting the countries of the Western Balkans on their path to European integration and membership in key European and Euro-Atlantic institutions" (Price 2021). This statement was repeated in all the mentioned recent speeches of Gabriel Escobar (Milić 2021; Ranković 2021; House Foreign Affairs Committee 2021).

However, this change has so far remained primarily rhetorical in the sense of putting additional emphasis on the EU future of the region. Still, it seems that in the future other measures might build on this rhetorical change. The administration could devote more money to boost reforms in the region, combined with political demands to the leaders of the states in this part of the world to speed up their alignment with the EU regulations and standards to ensure better relations with the new American administration. Still, this scenario is uncertain. The most significant help the EU would probably get from the new US administration is the mentioned financial and political help for economic integration of the region (which is perceived many on the West as a pre-step for the EU accession) and a joint approach to the Kosovo issues.

Cancellation of the separate dialogue between Belgrade and Pristina with the US mediation

Instead of maintaining a separate track for negotiation between Belgrade and Pristina with the mediation of Washington, the new

other countries in the region align with the US request in the future. 
administration switched back to full support for the Brussels dialogue led by the EU. Deputy vice Secretary Molly Montgomery announced this switch in February 2021 (VOA, N1 Belgrade 2021), and an official statement of the State Department later confirmed it (Price 2021). Grennel's position as the "Special Presidential Envoy for Serbia and Kosovo Peace Negotiations" does not exist in the new administration. A former State Department's "Special Representative for the Western Balkans" Matthew Palmer and his heir on the position of Deputy Assistant Secretary of State Gabriel Escobar started acting in coordination with the EU emissary for dialogue Miroslav Lajcak and other EU representatives. This is one of the most significant changes compared to Trump's approach to the region, and Trump and Grenell criticized it as a symbol of disengagement of the USA from the Western Balkans (Isufi 2021).

Still, this change does not mean that the new administration will become utterly inactive in this regard. The nomination of the retired career diplomat, Christopher Hill, for the next US ambassador in Belgrade indicates that the US plans to take a more active role in the Belgrade - Pristina dialogue, but under the formal mediation of the EU (Savković 2021). Hill was the US envoy for Kosovo in 1998-99, and he has tremendous experience in the region. The decision to nominate him even though he is retired already for years, and although it has been only two years since the current US ambassador Godfrey took his duty, additionally strengthens the perception that Hill is nominated with some sort of special task regarding the Belgrade - Pristina dialogue and that this will be his primary field of interest. Therefore, although the new administration canceled the separate dialogue track, it won't go to hibernation regarding this issue, and it might follow certain paths of the more active approach introduced by Trump's administration.

\section{Additional focus on issues of corruption, democracy, and human rights}

In early June 2021, the White House formally announced its Memorandum on Establishing the Fight Against Corruption as a Core United States National Security Interest (Biden 2021). Biden's administration declared that it would fight corruption not only in its state but also around the world since it "corrodes public trust; hobbles effective governance; distorts markets and equitable access to services; undercuts development efforts; contributes to national fragility, extremism, and migration; and provides authoritarian leaders a means to undermine democracies worldwide" (Biden 2021). Also, the new 
administration announced that it will focus on support for democracies worldwide and that human rights will be an essential topic in its international engagement. It was not an announcement of any kind of "crusader" campaign which would again "export" democracy by force. Still, this is a difference from the previous administration, which did not focus on these issues.

In its policy towards the Western Balkans, the USA will also focus comparatively more on these issues, considering that the quality of democracy and human rights is quite fragile in almost the whole region. At the same time, the level of corruption seems to be much higher than in the EU. The main instrument for such engagement might be targeted sanctions on individuals. In June, the new administration added the possibility to sanction corrupted individuals from the Western Balkans to the existing act on sanctioning from 2001 (RFL/RL 2021). This measure has not been used so far, so its first purpose is probably to deter and scare corrupted politicians that US sanctions might target them. ${ }^{4}$ Other instruments for the fight against corruption and support for democracy might be additional financial support for actors with better democratic performances and labelling of those who are backsliding in these fields. One form of implicit labelling could have been non-invitation to the global summit of democracies, which Biden will organize in early December 2021. According to the leaked preliminary list of invited, published by magazine Politico, the highest officials from Belgrade, Pristina and Sarajevo were initially not be invited to participate in this summit (Toosi 2021). Exclusion from this summit could have labelled these actors as non-democratic from Washington's point of view and sent negative signals to some future investors about the stability of their market.

However, the US eventually decided to invite Serbia to the mentioned summit (Nešić 2021). ${ }^{5}$ It is also still reluctant about using any sanctions towards individuals from the region, and it still pragmatically cooperates with all the regional leaders, as explained in the previous section. Therefore, this change so far remains only in the field of political narrative and is not as radical as some people expected. In the future, this change might become more critical. Still, it seems that the focus on these issues will depend on how countries from the region accommodate the US

4) James O'Brien, ex-aide of Madlen Albright with significant experience in the Western Balkan region, is nominated for the position of sanctions coordinator, which might also indicate that certain sanctions could target Western Balkan individuals.

5) At the moment of submission of this text, it was not definitely known if Bosnia and Herzegovina and Kosovo* were also invited to participate at the Summit. 
requirements in other (more important) issues, such as economic integration of the region, emancipation from the Russian and Chinese influence, solving of the open problems (such as Kosovo issue), or military cooperation (Krstić et al. 2021, 58).

\section{An active approach to Bosnia and Herzegovina}

The administration of Donald Trump did not pay too much attention to the issue of Bosnia and Herzegovina. On the other hand, in announcing its commitments to the Western Balkans, the State Department emphasized the reforms in Bosnia, especially the electoral reform (Price 2021). Robert Palmer, a diplomat with colossal experience in the region, was named a US State Department's Special Envoy for Electoral Reform in Bosnia and Herzegovina (Trkanjec 2021). This decision signaled how important progress in this regard is for the US interest in the region. Palmer announced that he would pressure all sides to make huge steps forward (Trkanjec 2021). Still, it seems that he is trying to reconcile the Bosniak and Croat approach firstly and negotiate with opposition parties from Republika Srpska in order to concentrate the pressure on Milorad Dodik in later phases (Slobodna Bosna 2021). He also mentioned that this issue is crucial for Secretary Blinken (Slobodna Bosna 2021).

However, this does not mean that the US will push for additional unitarization of Bosnia and Herzegovina, as some predicted, feared or hoped. In the leaked document, which presents an allegedly US document for the reform of the electoral system in $\mathrm{BiH}$, one of the goals was to secure acknowledgement of the Bosniak parties that the reform is about "a narrow objective of ensuring the right of others ${ }^{6}$ to run for office", and "not a leap towards civic state - which is unrealistic" (Slobodna Bosna 2021a). Palmer has also used the example of successful electoral reform in Mostar as a model for the whole of Bosnia and Herzegovina, emphasizing the words "limited and targeted" (Slobodna Bosna 2021). It means that the US will not push for a too ambitious plan and that it will try not to disturb relations with Croats and Serbs in Bosnia by demonstrating that the US is not planning to push for the civic state in $\mathrm{BiH}$, which would deprive entities and cantons with Serbian and Croatian majority of their numerous rights.

6) Others in this case means members of non-constitutive nations, such as Roma or Jews, in accordance with the Sejdic-Finci verdict of the European Court of Human Rights. 


\section{WHY IS BIDEN'S FOREIGN POLICY TOWARDS THE BALKANS SIMILAR TO TRUMPS?}

In the following paragraphs, we will try to analyze potential factors that influence the continuity and some changes in the new administration's approach to the Western Balkans compared to the course of the previous administration. We will divide these factors into three levels of analysis.

\section{Structural (global) level of analysis}

Structural theories usually do not tend to explain foreign policy, both if they are realists (Waltz 1979), liberals (Keohane 1989) or social constructivists (Wendt 1999). These approaches are therefore labelled as theories of international politics (Rose, 1999). However, certain theories of foreign policy also consider the structural factor. The best example is neoclassical realism, which focuses on the global level of analysis and takes the international position of the state as the independent variable for its foreign policy while adding many factors on state and individual levels as intervening variables (Dašić 2021, 127-157). Certain realists who tried to adjust their methodology to Foreign Policy Analysis research claim that we should focus first on the international system level, and if these are not well enough, continue analyzing the influence of interstate or intrastate levels (Mouritzen and Wivel 2014).

In this case, the structural approach can explain a big part of the picture with continuity in foreign policy. Competition of the US with China and Russia is a typical structural issue that stems from the logic of power distribution. Balance of power logic directs the US towards balancing (confronting) any rising Chinese or Russian influence in this region. Also, the enlargement of NATO seems to be American interest, which derives from the distribution of power and geopolitical logic. America wants to enlarge its net of allies and its effective control over military affairs in the rimland region of the Western Balkans. Focus on the economic integration of the Balkans might also be the consequence of the tendency to prevent further economic penetration of other powers to the Balkans and an attempt to try to control the most critical economic and financial processes in the region through the US-backed common market. The fact that this integration might be without the substantial support of the EU might also be explained from the structural reasons - the US wants its leading role in the process and believes more in its capacities than in the capabilities of its allies. 
Also, the decision to implement a more flexible approach towards the Kosovo issue has certain structural roots. Dialogue between Belgrade and Pristina with the mediation of the EU entered the structural crisis since 2017. Decrease of normative and transformative power of the EU due to various crises reduced the capacity of Brussels to broker new agreements for further normalization of relations between Belgrade and Pristina. The rise of populism in Belgrade and Pristina (a part of a more general trend of the rise of populism in democracies) also reduced the potential for additional compromises. Albin Kurti, a new leader in Pristina, openly denounced dialogue with Belgrade as a priority and emphasized that he would have a much less flexible approach than his predecessors. These factors induced the change in the US approach as well. Instead of expecting an express solution, Washington is now much more aware that the solution must be gradual. Therefore, even though the new administration canceled the separate track for negotiations in Washington, it seems that it will continue with a more balanced, flexible, and gradual approach to the dialogue between Belgrade and Pristina. Due to these changes, followed by the rise of challengers for the US unilateral power such as China and Russia, Washington is aware that it is not anymore 2008 when they thought that the status of Kosovo could be quite fast finally settled unilaterally and that very soon all other actors will recognize its independence.

These are just some structural factors that can explain the continuity in foreign policy towards the Western Balkans of Trump's and Biden's administrations. However, structural factors cannot explain everything. First, they cannot explain changes which exist in the relations towards the EU - like the fact that the US supports the EU enlargement to the Western Balkans much more vocally in Biden's administration than they used to during Trump's period, and that they decided to hand over the leading role in the Belgrade - Pristina negotiations back to the EU. Second, they cannot explain a more active approach to Bosnia and Herzegovina, nor additional focus on corruption, democracy, and freedom of speech compared to the previous administration. Therefore, we must focus on other argumentations to explain different parts of this jigsaw while acknowledging that structural arguments have solid explanatory power.

\section{State (internal) level of analysis}

Incentives from the internal politics level are considered not central (independent) but intervening variables in neo-classical realism (Živojinović 2008). On the other hand, the so-called Innenpolitik 
approaches consider internal politics the primary determinant of foreign policy (Rose 1998). Significant in this regard are bureaucratic models of Foreign Policy Analysis, which put special focus on the role of bureaucracy, their standard operative procedures, perceptions, particular interests, and internal bargaining in the foreign policymaking process (Hudson, Day 2020, 89-121). Somewhere in between are approaches which consider the foreign policy as a "two-level game", played simultaneously on the international and domestic levels (Putnam 1988), as well as approaches that claim that internal factors can influence one important element (but not everything) in the foreign policy of the particular state, such as democratic peace and liberal peace theories (Russett et al. 1995) or social constructivist models of Foreign Policy Analysis (Kubalkova 2001).

There are plenty of internal factors which might influence US foreign policy. However, considering that the Western Balkans is not a region that is of the biggest priority for the US, many concrete decisions will be made on lower levels and not too many actors will be interested in it (Krstić et al. 2021, 7-8). From the institutional point of view, this means that State Department, despite the relative decline of its role in comparison to the rising importance of the White House since the mid-20 $0^{\text {th }}$ century (Rossati, Scott 2011, 129), still has a crucial role in the creation and implementation of the most significant part of the US foreign policy towards the region. At first sight, this might lead us to the conclusion that State Department bureaucracy is the biggest reason why there is no significant shift from the previous administration compared to Biden's. However, this factor cannot alone explain patterns of continuity and change. During the last two years of Trump's administration, the White House (especially Trump's emissary Richard Grenell) took over the leading role in the US policy towards Western Balkans from the State Department - which means that there is not complete institutional continuity in this regard. Despite this fact, State Department today follows many aspects of Trump's White House approach instead of ultimately coming back to the policy towards Western Balkans during Obama's administration when the State Department played the crucial role in its creation and implementation. Also, some people in the most critical positions for Western Balkan policy in this branch of bureaucracy are different than during Trump's period, such as Victoria Nuland or Moly Montgomery.

Other branches of bureaucracy, such as the military (Department of Defense), or agencies like USAID, also have a certain role in the US Western Balkan policy, but comparatively much smaller than State Department and circle around President (Jentleson 2013, 45-53). 
Congress has a certain influence, especially in agenda-setting, but its impact is incomparable to the executive. Still, Congressional caucuses and lobbies are trying to put certain issues in the spotlight and pressure the executive regarding some directions of action. During the last months, there were two cases when different Congressmen wrote open letters to the President. Seven pro-Albanian oriented members of the House of Representatives called the administration to pressure Belgrade regarding the situation in Kosovo and its dialogue with Pristina (Tanjug 2021). Letter of the other seven members of the House advocated for pressure on the Serbian regime to fight corruption and ensure media freedom (Vijesti 2021). However, this has not influenced any substantial changes in the administration approach so far. Therefore, it could not be said that they affect the US policy towards the region in a significant manner.

All the mentioned institutional actors are, to a certain extent, influenced in their decision-making process by various factors, such as the impact of organized groups and lobbies, media, public opinion, epistemic communities, knowledge-based experts, etc. (Jackobs and Page, 2005, 107-109). Media and public opinion in the US during the 1990s generally had negative attitudes towards Serbs, mixed towards Croats, and positive towards Albanians and Bosniaks. However, since the Western Balkans is not anymore one of the most critical areas for the USA, as it was during the 1990s, the interest of media and public opinion for regional issues nowadays seems to be considerably low, as well as their influence on the US foreign policy towards the region. Epistemic communities and knowledge-based experts also have a certain impact, but the number of experts for the Western Balkans has been considerably reduced during the last decade. On the other hand, the influence of the lobbies is still considered necessary. However, considering that the Albanian lobby seems the strongest, its impact cannot explain the continuity in a somewhat more flexible position towards the Kosovo issue. To sum up, internal factors can also define one part of the US foreign policy towards the Western Balkans, but they seem to be less critical than structural factors.

\section{Individual level of analysis}

Many scholars in the field of Foreign Policy Analysis focus on the political psychology of leaders (Hudson and Day 2020, 39-74), with particular emphasis on the influence of socialization and personal biography on their operational code (Walker, 1990), mental schemas (Rosati 2000) and analogical reasoning (Houghton 1996). Starting assumption of such an approach is that leaders are crucial for decision 
making and that their personal history shapes the way how they view the world. Neoclassical realism also considers the influence of leaders' characteristics, but only as an intervening variable, while FPA considers it the most important factor. Social-constructivist approaches in FPA as well consider the individual world view, its values and socialization as essential factors, although they tend to make a balance between the influence of personal agency and broader social structure.

Based on the logic of this approach, we should have expected substantial change of many aspects of US foreign policy towards the Western Balkans in the last year. The fact that Biden sees the world quite differently was one of the most critical factors for the expectation of change. Also, unlike Donald Trump, who had no previous experience in the region, Joseph Biden was a very active follower of Balkan affairs since his first visit to Yugoslavia in 1979, especially during the 1990s (Krstić et al. 2021, 5). Biden also advocated a harsher approach towards Serbia during the 1990s (Krstić et al. 2021, 5-7). These facts could have led us to conclude that we should expect a radical change compared to Trump's policy to Serbia, which some actors considered too mild. However, this did not happen. One of the explanations might be the fact that Biden's attitudes towards the Western Balkans were not so strong, but that they were more the consequence of his position and interests when Biden was a vice-president, he was not hawkish against Serbia, as he was during his period in the Senate when he cooperated with many pro-Albanian senators and lobbyists (Krstić et al. 2021, 7).

Still, President does not make this decision alone, but after numerous advice and consultation with his advisors, especially National Security Council (NSC) members. Therefore, many consider that the White House or Presidency is actually "the center of foreign affairs government" (Wittkopf et al. 2006). Neither Vice President Kamala Harris nor National Security Advisor Jake Sulivan have significant experience dealing with this region. Phillip Gordon is the only person in the circle around President and Vice-President with considerable experience in dealing with this region. He was Hillary Clinton's Assistant Secretary for Europe and Eurasia. Although milder than Biden's, his attitudes towards the Western Balkans were more-less on the same track (Krstić et al. 2021, 24-26). Therefore, the personal beliefs of people in the Presidency cannot explain the continuity with Trump's foreign policy. It seems that their personal characteristics and views simply do not matter, because the Western Balkan policy is not essential at this moment.

Therefore, it seems even more important to focus on the level of the State Department and personal beliefs of the key people for 
Western Balkan in this branch of government. State Secretary Blinken was director for European affairs in President Clinton's NSC during the bombing of Yugoslavia in 1999 (Krstić et al. 2021, 10-12). The third person in the State Department, undersecretary Victoria Nuland, used to be John Kerry's assistant secretary for Europe and Eurasia from 2013 to 2017 (Krstić et al. 2021, 18-20). One of the new deputy assistant secretaries for Europe and Eurasia is Moly Montgomery, who previously worked for the Albright-Stonebridge group and who is close with former state secretary Madlen Albright (Krstić et al. 2021, 3435). A close associate of Secretary Albright was also James O'Brien, nominated for the position of Coordinator for Sanctions, while Christopher Hill, recently nominated for the next US ambassador in Serbia, also closely cooperated with Albright and Richard Holbrook. The new assistant secretary for Europe and Eurasia is Karen Donfired, a person with good knowledge of current affairs in the Western Balkans, who heavily criticized Trump when she was President of the German Marshall Fund of the United States. According to these facts, it would be more logical to return to Obama's or Clinton's approach to the region instead of continuity with Trump in essential aspects. However, some of the mentioned changes (such as the bigger support to the EU integration of the region or cancelation of the separate track for Belgrade-Pristina negotiation) could be explained through the difference in perceptions and values which new decision-makers have in comparison to the previous.

In addition, it is important to emphasize that some of the people in important positions in the State Department were also influential during Trump's period. Matthew Palmer, the new emissary for electoral reform in Bosnia, used to be deputy assistant secretary for Europe and Eurasia and special emissary for the Western Balkans during the previous administration (Krstić et al. 2021, 30-33). Gabriel Escobar, who replaced Palmer in his positions, used to be the second person in the US embassy in Belgrade until 2021. Even Molly Montgomery had a role in Trump's administration - she used to be an advisor of vice-president Mike Pence until 2018. Therefore, the presence of these people in important positions in the new administration might explain a part of the reasons for continuity. However, since these people are not in the key positions, and since there are many new people, the explanation for continuity based on the individual level of analysis seems to be weaker than that coming from the structural and even from the state level of analysis. 


\section{CONCLUSION}

The administration of Joseph Biden has substantial continuity in its Western Balkan policy with their Republican predecessors. Primary focus on economic integration; a more balanced approach to the Kosovo issue and dialogue of Belgrade and Pristina; pragmatic cooperation with all Western Balkan leaders regardless of their democratic performances; countering the rising influence of Russia and China and support for further expansion of NATO - these are all essential elements of continuity between two administrations. There are also certain peculiarities of the new administration in comparison to the previous: more vocal support to the EU integration of the Western Balkans; cancelation of the separate dialogue between Belgrade and Pristina in Washington and support to the dialogue in Brussels; more active approach to Bosnia and Herzegovina and additional (narrative) emphasis on the issues of democracy, human rights, and the rule of law. Still, these differences seem to be less crucial (and primarily focused on rhetoric) than the mentioned essential elements of policy continuity.

This article has also examined why is there more continuity than change. Structural factors play the most important role in determining such an outcome. However, their explanatory potential has limits. Therefore, it is necessary to add certain factors from the state and individual levels of analysis. Further studies of this topic should conduct more in-depth studies about the interaction of factors from different levels of analysis to more precisely theorize crucial variables that shape the US foreign policy towards the Western Balkans. Also, further studies should conduct a comparative analysis of the US foreign policy towards different regions in order to answer some of the following important questions: how much continuity exists between Biden's and Trump's foreign policy; in which regions are they similar and in which quite different; and finally which factors influence these patterns of continuity or differentiation.

\section{REFERENCES}

Abrams, Elliot. 2021. "Obama's Third Term - or Bill Clinton's?" The Hill. February 14, 2021. https://thehill.com/opinion/international/538768obamas-third-term-or-bill-clintons.

Andelman, David A. 2021. "Biden's foreign policy is a revolutionary change from the Trump era." CNN Opinion. February 5, 2021. https://edition.cnn. com/2021/02/05/opinions/joe-biden-foreign-policy-donald-trump-andelman/index.html. 
Atlantic Council. 2021. "The big takeaways from Biden's first foreign-policy speech." New Atlanticist. February 4, 2021. https://www.atlanticcouncil. org/blogs/new-atlanticist/the-big-takeaways-from-bidens-first-foreignpolicy-speech/.

Beta. 2020. "Dačić: Vučić oštro odbio predlog SAD koji podrazumeva priznanje Kosova.“ Danas. September 3, 2020. https:/www.danas.rs/vesti/politika/dacic-vucic-ostro-odbio-predlog-sad-koji-podrazumeva-priznanje-kosova/.

Biden, Joseph R. 2021. "Memorandum on Establishing the Fight Against Corruption as a Core United States National Security Interest." The White House. June 3, 2021. https:/www.whitehouse.gov/briefing-room/presidential-actions/2021/06/03/memorandum-on-establishing-the-fight-against-corruption-as-a-core-united-states-national-security-interest/.

Bisley, Nick. 2021. "More continuity than change in Biden's Asia strategy." East Asia Forum. September 28, 2021. https://www.eastasiaforum. org/2021/09/28/more-continuity-than-change-in-bidens-asia-strategy/.

CDDRI. 2020. “Analiza dokumenata potpisanih u Beloj kući.“ Centar za društveni dijalog i regionalne inicijative. Last accessed October 152021. https:/cddri.rs/wp-content/uploads/2020/09/Analiza-dokumenata-potpisanih-u-Beloj-ku\%C4\%87i_WEB001.pdf.

Dašić, Marko. 2021. "Međunarodni politički položaj kao odrednica spoljne politike malih država: studija slučaja Republike Srbije od 2000. do 2018. godine." PhD diss. University of Belgrade - Faculty of Political Science.

Đukanović, Dragan, Krstić, Milan. 2021. "Regionalna saradnja na Zapadnom Balkanu - dugoročno čekanje na članstvo u Evropskoj uniji i/ili „Balkanska unija.“ Srpska politička misao 71 (1): 9-26. doi: https://doi. org/10.22182/spm.7112021.1.

EWB. 2019. "Trump supports mutual recognition in new letters to Vucic and Thaci." European Western Balkans. February 2, 2019. https://europeanwesternbalkans.com/2019/02/15/trump-supports-mutual-recognition-new-letter-vucic-thaci/

Freedom House. 2021. "Nations in Transit 2021: Serbia." Freedom House. Last Accessed October 15, 2021. https://freedomhouse.org/country/ser$\mathrm{bia} /$ nations-transit/2021.

Houghton, David Patrick. 1996. "The Role of Analogical Reasoning in Novel Foreign-Policy Situations." British Journal of Political Science 26(4): 523-552. doi: https://doi.org/10.1017/S0007123400007596.

House Foreign Affairs Committee. 2021. "US Engagement in the Western Balkans." YouTube. October 28, 2021. https:/www.youtube.com/ watch?v=Re3vIJex4VA.

Hudson, Valerie M., Day, Benjamin S. 2020. Foreign Policy Analysis: Classic and Contemporary Theory. New York: Rowman \& Littlefield.

Isufi, Perparim. 2021. "Trump Voices Concerns Over 'Abandoned' Kosovo-Serbia Agreements.” Balkan Insight. November 12, 2021. https:// 
balkaninsight.com/2021/11/12/trump-voices-concerns-over-abandonedkosovo-serbia-agreements/.

Jacobs, Lawrence R., Page, Benjamin I. 2005. "Who Influences U.S. Foreign Policy?" American Political Science Review 99(1): 107-123. doi: https:// doi.org/10.1017/S000305540505152X.

Jentleson, Bruce W. 2013. American Foreign Policy: The Dynamic of Choice in the 21st century. New York: W.W. Norton \& Company.

Kakissis, Joannna. 2020. "How A Trump Diplomat Helped To Bring Down Kosovo's Government.“ National Public Radio. June 5 2020. https:// www.npr.org/2020/06/05/870227931/how-a-trump-diplomat-helpedbring-down-kosovos-government.

Keohane, Robert O. 1989. Theory of World Politics: Structural Realism and Beyond. New York: Routledge.

Kosovo online/Gazeta express. 2021. "Blinken: Pozdravljam rad Trampa na sporazumu Beograda i Prištine.” Kosovo online. January 19, 2021. https:// www.kosovo-online.com/vesti/politika/blinken-pozdravljam-rad-trampa-na-sporazumu-beograda-i-pristine-19-1-2021.

Krstić, Milan, Nedeljković, Stevan, Živojinović, Dragan, Dašić, Marko, Milenković, Dušan, Vučinić, Branko. 2021. Srbija i Amerika u Bajdenovoj eri. Beograd: Centar za društveni dijalog i regionalne inicijative. https://cddri.rs/wp-content/uploads/2021/03/Srbija-i-Amerika-u-Bajdenovoj-eri_FINAL-web.pdf.

Kubalkova, Vendulka. 2001. Foreign Policy in a Constructed World. New York: Routledge.

Kuzmanovski, Blagoja. 2017. "Hojt Ji u Skoplju: Hitno omogućiti formiranje Vlade." Radio Slobodna Evropa. May 1, 2017. https://www.slobodnaevropa.org/a/hojt-brajan-ji-u-skoplju/28462308.html.

Labott, Elise. 2021. "When the White House Changed Hands, It Changed Tone but Not Policies." Foreign Policy. September 22, 2021. https://foreignpolicy.com/2021/09/22/biden-us-policy-trump-legacy-foreign-policy-aukus/.

Macias, Amanda, Higgins, Tucker. 2018. "Trump says defending tiny NATO ally Montenegro could result in World War III." CNBC. July 18, 2018. https://www.cnbc.com/2018/07/18/trump-defending-nato-ally-montenegro-could-result-in-world-war-3.html.

Milić, Predrag. 2021. "Eskobar: Nova administracija biće vrlo aktivna u regionu, imamo odgovor na uticaj Rusije." Voice of America, October 15, 2021. https://www.glasamerike.net/a/rajnke-crnogorski-multikulturalizam-bio-faktor-stabilizacije-regiona-alarmantna-erozija-po\%C5\%A1tovanja-razli\%C4\%8Ditosti/6272015.html.

Mouritzen, Hans, and Wivel, Anders. 2014. "Contrasting Allison, challenging Waltz: Geopolitics and the study of foreign policy." International Politics Review 2: 42-46. doi: doi:10.1057/ipr.2014.8.

Nedeljkovic, Stevan, Krstic, Milan. 2021. "Deset godina sporazumevanja Beograda i Prištine." Centar za društveni dijalog i regionalne inicijative. Last 
accessed October 15 2021. https://cddri.rs/wp-content/uploads/2021/11/ Normalizacija-Deset-godina-sporazumevanja-web.pdf.

Nešić, Milan. 2021. "Srbija pozvana na Bajdenov Samit za demokratiju." Voice of America. November 12, 2021. https://www.glasamerike.net/a/ bajden-samit-srbija-kosovo/6310756.html.

Politika. 2021. "Eskobar: Dodika ne podržava ni Srbija.“ Politika. November 11, 2021. https://www.politika.rs/sr/clanak/491487/Eskobar-Dodika-ne-podrzava-ni-Srbija.

Price, Ned. 2021. "Press Statement of the State Department: US Commitment to the Western Balkans." U.S. Department of State. April 26, 2021. https:// www.state.gov/u-s-commitment-to-the-western-balkans/.

Putnam, Robert D. 1988. "Diplomacy and Domestic Politics: The Logic of Two Level Games." International Organization 42(3): 427-460. doi: https://doi.org/10.1017/S0020818300027697.

Ranković, Rade. 2021. "Eskobar: SAD gledaju na Balkan kroz prizmu 21. veka.“. Voice of America. October 26, 2021. https://www.glasamerike. net/a/sjedinjene-drzave-sad-eskobar-beograd-balkan/6286216.html.

RFE/RL. 2018. "Bolton Says U.S. Won't Oppose Kosovo-Serbia Land Swap Deal." Radio Free Europe - Radio Liberty. August 24 2018. https://www. rferl.org/a/bolton-says-u-s-won-t-oppose-kosovo-serbia-land-swapdeal/29451395.html.

RFE/RL. 2021. "U.S. 'Modernizes' Sanctions Policy For Western Balkans To Go After Corruption." Radio Free Europe/Radio Liberty. June 9, 2021. https://www.rferl.org/a/western-balkans-us-modernizes-sanctionscorruption/31297669.html.

Rose, Gideon. 1998. Neoclassical realism and theories of foreign policy. World Politics 51(1): 144-172. doi: https://doi.org/10.1017/ S0043887100007814.

Rossati, Jarel A. 2000. "The Power of Human Cognition in the Study of World Politics.” International Studies Review 2(3): 45-75. doi: https://doi. org/10.1111/1521-9488.00215.

Rossati, Jerel A., James, Scott, M. 2011. The Politics of United States Foreign Policy. Boston, MA: Cengage Learning.

RSE. 2021. "Biden u pismu predseniku Srbije: SAD će podržati postizanje trajnog sporazuma sa Kosovom". Radio Slobodna Evropa. February 7, 2021. https://www.slobodnaevropa.org/a/31090319.html.

Russett, Bruce, Layne, Christopher, Spiro, David E., Doyle, Michael W. 1995. "The Democratic Peace" International Security 19(4): 164-184. doi: https://doi.org/10.2307/2539124.

Savković, Marko. 2021. "Novi singal rešenosti SAD da se otvoreni problemi zatvore: Kristofer Hil četvrti put na Zapadnom Balkanu." Normalizacija. Last accessed October 15, 2021. https://normalizacija.rs/novi-signalresenosti-sad-da-se-otvoreni-problemi-zatvore/.

Singh, Maanvi. 2020. 'Joe Biden says 'this is not a third Obama term' in 
first sit-down interview." The Guardian. November 25, 2020. https:// www.theguardian.com/us-news/2020/nov/24/joe-biden-nbc-interviewpresidency.

Slobodna Bosna. 2021. "Bidenov čovjek za izbornu reformu u BiH otkrio karte: Pristup mu podsjeća na 1994. kada je okončan rat Hrvata i Bošnjaka." Slobodna Bosna. October 27, 2021. https://www.slobodna-bosna.ba/ vijest/221202/bidenov_chovjek_za_izbornu_reformu_u_bih_otkrio karte_pristup_mu_podsjeca_na_1994_kada_je_okonchan_rat_hrvata_i_ bosnjaka.html.

Slobodna Bosna. 2021a. "SB ekskluzivno otkriva; Palmerov plan za reform izbornog zakona I razbijanje probosanskog bloka: $\mathrm{Na}$ jednoj strain su SDP, SBB, NiP i Naša stranka, a na drugoj SDA i DF." Slobodna Bosna. October 26, 2021. https://www.slobodna-bosna.ba/vijest/221166/sb ekskluzivno_otkriva_palmerov_plan_za_reformu_izbornog_zakona_i_ razbijanje_probosanskog_bloka_na_jednoj_strani_su_sdp_sbb_nip_i nasa_stranka_a_na_drugoj_sda_i_df_foto.html.

Tanjug. 2021. "'Da dobije priznanje kao nezavisna država': Albanski lobisti pisali Bajdenu, traže osudu nedavnih dešavanja na KiM, a imaju i posebne želje." Blic. October 5, 2021. https://www.blic.rs/vesti/politika/da-dobijepriznanje-kao-nezavisna-drzava-albanski-lobisti-pisali-bajdenu-trazeosudu/sf23ere.

Toosi, Nahal. 2021. “An 'Illustrative Menu of Options': Biden's big democracy summit is a grab bag of vague ideas." Politico. November 4, 2021. https://www.politico.com/news/2021/11/04/biden-democracy-summittechnology-519530.

Trkanjec, Zeljko. 2021. "US envoy to press for long-delayed reforms in Bosnia." Euractiv. October 27, 2021. https://www.euractiv.com/section/ enlargement/news/us-envoy-to-press-for-long-delayed-reforms-inbosnia/.

USEmbassy Serbia.2021. "DASEscobarBSF 2021 KeynoteAddress." YouTube. October 28, 2021. https://www.youtube.com/watch?v=X5PO9lzJV4c.

US Mission Germany. 2019. "Statement on Western Balkans Mini-Schengen." US Embassy \& Consulates in Germany. November 14, 2019. https:// de.usembassy.gov/statement-on-western-balkans-mini-schengen/.

Vijesti. 2021. "US Congress members ask Biden to engage Serbia's govt on rooting out corruption." N1. November 6, 2021. https://rs.n1info.com/ english/news/us-congress-members-ask-biden-to-engage-serbias-govton-rooting-out-corruption/.

VOA, N1 Belgrade. 2021. "US official: Aim to normalize Serbia-Kosovo relations." N1. February 24, 2021. https://rs.n1 info.com/english/news/usofficial-aim-to-normalise-serbia-kosovo-relations/.

Walker, Stephen G. 1990. "The Evolution of Operational Code Analysis." Political Psychology11(2):403-418. doi:https://doi.org/10.2307/3791696.

Waltz, Kenneth. 1979. Theory of International Politics. Reading, MA: Addison-Wesley Publishing Company. 
Wendt, Alexander. 1999. Social Theory of International Politics. Cambridge: Cambridge University Press.

Wittkopf, Eugene R., Jones, Christopher M., Kegley, Charles W. 2008. American Foreign Policy: Pattern and Process. Belmont, CA: Thomson Wadsworth.

Živojinović, Dragan. 2008. "Neoklasični realizam u teorijama međunarodnih odnosa." Godišnjak Fakulteta političkih nauka 2(2): 367-392. 


\author{
Милан Крстић* \\ Универзитет у Београду - Факултет политичких наука
}

\title{
КОНТИНУИТЕТ И ПРОМЕНЕ СПОЉНЕ ПОЛИТИКЕ САД ПРЕМА ЗАПАДНОМ БАЛКАНУ ЗА ВРЕМЕ ПРВЕ ГОДИНЕ БАЈДЕНОВЕ АДМИНИСТРАЦИЈЕ: ТРЕЋИ ОБАМИН ИЛИ ДРУГИ ТРАМПОВ МАНДАТ?
}

\begin{abstract}
Резиме
Многи аналитичари очекивали су радикалну промену у спољној политици председника Џозефа Бајдена, посебно у поређењу са претходним председником Доналдом Трампом. Годину дана након изборне победе, мишљења о томе колико је Бајден заиста променио спољну политику САД су подељена и варирају од оних који виде револуционарну промену до оних који виде само разлику у тону у већини кључних аспеката. Овај рад настоји да допринесе дебати кроз анализу континуитета и промене у спољној политици нове администрације према региону Западног Балкана. Иако су многи очекивали да Бајденова политика буде сличнија приступима председника Барака Обаме или чак Била Клинтона, овај рад аргументује да нова администрација задржава значајан део заједничког курса са Трамповом. Међутим, приметне су и одређене промене и модификације, али чини се да оне нису важније од елемената континуитета који постоје између односа две администрације према региону. Рад се такође обраћа узроцима оваквог континуитета и тврди да главни разлог за то лежи у структуралним факторима на нивоу међународног система. Остали разлози се могу наћи на државном (унутрашњем нивоу), као и на индивидуалном нивоу анализе.
\end{abstract}

Кључне речи: спољна политика САД, Западни Балкан, Бајден, Трамп, континуитет, промена, нивои анализе

Контакт: milan.krstic@fpn.bg.ac.rs

Овај рад је примљен 14. новембра 2021. године, а прихваћен за штампу на телефонском састанку Редакције, 15. новембра 2021. године. 